\title{
ANALISIS HUKUM TERHADAP FRAUD (KECURANGAN) DALAM E-PROCUREMENT DI LPSE KABUPATEN TRENGGALEK
}

\author{
Petrus Aji Brata, Staf Badan Perencanaan Pembangunan, Penelitian, dan Pengembangan Daerah \\ Pemkab Trenggalek, E-mail: ajibrata@yahoo.co.id
}

\begin{abstract}
ABSTRAK
Penyelenggaraan pemerintahan yang baik dan bersih (Good Governance and Clean Government), perlu didukung dengan pengelolaan keuangan yang efektif dan efisien. Salah satu perwujudannya adalah dengan pelaksanaan proses Pengadaan Barang/Jasa Pemerintah secara elektronik (EProcurement). Terdapat hambatan-hambatan dalam penerapannya sehingga membutuhkan penelitian serius. Penelitian yuridis empiris di Kabupaten Trenggalek ini menunjukkan bahwa dalam proses pengadaan barang/jasa secara elektronik masih membutuhkan sosialisasi kepada pihak penyedia karena masih banyak pihak penyedia yang kebingungan/belum mengerti proses $E$ Procurement, E-Procurement masih membutuhkan pengembangan dalam berbagai aspek, terutama dalam aspek tingkat kemampuan sumber daya manusia, aspek kondisi infrastruktur dan pengaturan sistem pendukung E-Procurement serta dalam aspek pengawasan prosedur. Kemajuan teknologi semakin pesat, dan kemajuan kecurangan teknologi semakin tinggi, namun Fraud/kecurangan dalam E-Procurement belum diatur secara khusus dalam Perpres No. 4 Tahun 2015 tentang Perubahan Keempat Atas Peraturan Presiden Nomor 54 Tahun 2010 tentang Pengadaan Barang/Jasa Pemerintah.
\end{abstract}

Kata Kunci: E-Procurement; Elektronik; Fraud; Pengadaan Barang/Jasa.

\section{PENDAHULUAN}

Tata pemerintahan yang baik dan bersih (Good Governance and Clean Government) adalah seluruh aspek yang terkait dengan kontrol dan pengawasan terhadap kekuasaan yang dimiliki Pemerintah dalam menjalankan fungsinya melalui institusi formal dan informal, sehingga Pemerintah harus melaksanakan prinsip-prinsip akuntabilitas dan pengelolaan sumber daya secara efisien, serta mewujudkannya dengan tindakan dan peraturan yang baik dan tidak berpihak (independen), serta menjamin terjadinya interaksi ekonomi dan sosial antara para pihak terkait (stakeholders) secara adil, transparan, profesional, dan akuntabel. ${ }^{1}$

Penyelenggaraan pemerintahan yang baik dan bersih, perlu didukung dengan pengelolaan keuangan yang efektif dan efisien. Salah satu perwujudannya adalah dengan pelaksanaan proses Pengadaan Barang/Jasa Pemerintah secara elektronik, yaitu Pengadaan Barang/Jasa yang dilaksanakan dengan menggunakan teknologi informasi dan transaksi elektronik sesuai dengan ketentuan peraturan perundang-undangan. ${ }^{2}$

Pelaksanaan E-Procurement diatur melalui Peraturan Presiden Nomor 8 Tahun 2006 tentang Perubahan Keempat Atas Keputusan Presiden Nomor 80 Tahun 2003 tentang Pedoman Pelaksanaan Pengadaan Barang/Jasa Pemerintah. E-Procurement mulai diterapkan sejak tahun 2007 dengan berdirinya Lembaga Kebijakan Pengadaan Barang/Jasa Pemerintah (LKPP). ${ }^{3}$

1 I Umum, Penjelasan Atas Peraturan Presiden Republik Indonesia Nomor 54 Tahun 2010 Tentang Pengadaan Barang/Jasa Pemerintah.

2 Direktorat e-Procurement LKPP, "Buku manual SPSE v.3.5", 2012, h.1.

3 Susan Andriyani, "Analisis Efektivitas Dalam Penerapan Pengadaan Barang Dan Jasa Secara Elektronik (E-Procurement) Serta Peranan Lembaga Pengawas Terhadap Pengadaan Barang Dan 
Penyelenggaraan Pengadaan Barang/Jasa Pemerintah secara elektronik diatur dalam Peraturan Presiden nomor 54 Tahun 2010 tentang Pengadaan Barang/Jasa Pemerintah, dan sebagaimana ketentuan dalam pasal 131 ayat (1) bahwa pada tahun $2012 \mathrm{~K} / \mathrm{L} / \mathrm{D} / \mathrm{I}$ wajib melaksanakan Pengadaan Barang/Jasa secara elektronik untuk sebagian/seluruh paket-paket pekerjaan. Selain itu dalam Perpres 54 Tahun 2010 juga mengatur mengenai Layanan Pengadaan Secara Elektronik (LPSE) sebagai unit kerja K/L/D/I untuk menyelenggarakan sistem pelayanan Pengadaan Barang/Jasa secara elektronik yang ketentuan teknis operasionalnya diatur oleh Peraturan Kepala LKPP No. 2 Tahun 2010 tentang Layanan Pengadaan Secara Elektronik. LPSE dalam menyelenggarakan sistem pelayanan Pengadaan Barang/Jasa secara elektronik wajib memenuhi ketentuan sebagaimana yang ditentukan dalam Undang-undang Nomor 11 Tahun 2008 tentang Informasi dan Transaksi Elektronik. ${ }^{4}$

Salah satu tujuan utama pengadaan barang/jasa secara elektronik adalah mengurangi persaingan usaha yang tidak sehat dan fraud (kecurangan) yang bisa terjadi. Penyelenggaraan pengadaan barang/jasa yang tidak sehat berdampak pada kerugian yang akan ditanggung masyarakat, termasuk rendahnya kualitas pelayanan yang diterima dari pemerintah. Meskipun telah diatur dengan aturan hukum yang jelas dan mengikat, pada kenyataannnya ada beberapa penyimpangan dalam proses pengadaan barang dan jasa. ${ }^{5}$

Kendati E-Procurement menggunakan internet sebagai intrumen bantu, namun bukan berarti lahirnya kesepakatan antara panitia pengadaan/offeree dengan peserta penyedia barang/offeror terjadi dalam internet sebagaimana e-Commerce. E-Procurement belum murni paperless transaction (sehingga keabsahan kontraknya tidak perlu diragukan), karena selain memasukkan data lewat portal/website, offeror diwajibkan pula memberikan dokumen penawaran dan data lain yang terkait dalam bentuk cetak hard copy kepada offeree. Akseptasi terjadi pada saat dikeluarkannya Surat Keputusan Penetapan Penyediaan Barang dan Jasa (SKPPBJ) yang menunjuk salah seorang peserta lelang/offeror sebagai pemenang lelang. Dengan kata lain, E-Procurement masih menekankan pada physical form (bentuk nyata dan konkret) atau paper based transaction yaitu belum murni menjalankan perdagangan secara elektronik layaknya e-Commerce, sehingga kaidah hukum perjanjian tetap berlaku. ${ }^{6}$

Penyelenggaraan E-Procurement di LPSE Kabupaten Trenggalek tersebut tidak selalu berjalan lancar, ada hambatan yang terjadi dalam penerapannya. Hambatan-hambatan tersebut membuat para offeror sebagai peserta lelang mengeluhkan kinerja dan kesiapan

Jasa Pemerintah", diunduh dari http:/lib.ui.ac.id/file?file=digital/20302458-T30642\%20 \%20Analisis\%20efektivitas.pdf, pada tanggal 20 April 2017 Pukul 08:31.

${ }^{4}$ Direktorat e-Procurement LKPP, loc. cit.

${ }^{5}$ Maria Avilla Cahya Arfanti, "Pelaksanaan Sistem E-Procurement dalam Pengadaan Barang/Jasa Pemerintah Untuk Mencegah Terjadinya Persekongkolan Tender", diunduh dari http://download.portalgaruda.org/article.php?article $=188095$ \&val $=6466 \&$ title $=$ PELAKSANAAN\% 20SISTE M\%20E-

PROCUREMENT\%20DALAM\%20PENGADAAN\%20BARANG/IASA\%20PEMERINTAH\%20UNTU K\%20MENCEGAH\%20TERJADINYA\% 20PERSEKONGKOLAN\%20TENDER\%20(Studi\%20di\%20Di nas\%20Pekerjaan\%20Umum, \%20Perumahan,\%20dan\%20Pengawasan\%20Bangunan \%20Kota\%20Malang L, pada tanggal 20 April 2017 Pukul 08.31.

6 Susan Andriyani , op. cit., h.4. 
LPSE Kabupaten Trenggalek. Selain itu pihak LPSE Trenggalek sendiri kelihatannya juga belum siap dengan sistem ini, kalau LPSE dan kontraktor lokalnya saja masih awam, hal ini akan menjadi celah bagi mereka yang lebih menguasai IT untuk melakukan upaya yang tidak fair. ${ }^{7}$ Gangguan pertama terjadi pada tanggal 7 Mei 2012, dimana kabel fiber optic (FO) jaringan astinet milik PT Telkom yang menuju server LPSE Trenggalek dipotong orang tak dikenal. Sedangkan gangguan kedua terjadi pada tanggal $15 \mathrm{Mei}$, server laman LPSE mendapat kiriman bom data dalam jumlah besar sehingga traffic meningkat tajam dan mengakibatkan proses pengiriman dokumen lelang macet total. ${ }^{8}$ Dalam pengadaan barang/jasa pemerintah secara elektronik (E-Procurement) seperti yang di atur Pasal 17 ayat (2), "Para Pihak yang melakukan Transaksi Elektronik sebagaimana pada ayat (1) wajib beriktikad baik dalam melakukan interaksi dan/atau pertukaran Informasi Elektronik dan/atau Dokumen Elektronik selama transaksi berlangsung" ${ }^{9}$

Setiap tindakan kriminal, selalu didorong atau dipicu oleh suatu kondisi dan perilaku penyebab terjadinya. Banyak ahli dan organisasi profesi mengungkapkan pendorong atau penyebab fraud dalam Teori $\mathrm{C}=\mathrm{N}+\mathrm{K}$, teori ini dikenal di jajaran atau profesi kepolisian yang menyatakan bahwa Kriminal (C) sama dengan Niat (N) dan Kesempatan (K). Teori ini sangat sederhana dan gambling karena meskipun ada niat melakukan fraud, bila tidak ada kesempatan tidak akan terjadi, demikian pula sebaliknya. ${ }^{10}$

Menurut W. Steve Albrecht dan Chad D. Albrecht dalam buku mereka, Fraud Examination, fraud didefinisikan sebagai:

A Generic term, embracing all multi various means which human ingenuity can devide and which are resorted to by one individual to get an advantage over another by false representation No divinize and invariable rule can be laid down as a general proposition in defining fraud, as it include surprise trickery, cunning and unfair ways by which another is cheated. Theory boundaries defining is are those which limit human knavery. ${ }^{11}$

\section{METODE PENELITIAN}

Dalam penelitian hukum empiris ini, yaitu penelitian yang membahas bagaimanakah aspek hukum terhadap fraud dalam E-Procurement menurut Peraturan Presiden Nomor 4 Tahun 2015 Tentang Perubahan keempat atas Peraturan Presiden Nomor 54 Tahun 2010 Tentang Pengadaan Barang/Jasa Pemerintah. Dalam jenis penelitian ini metode pendekatan yang digunakan adalah pendekatan perundang-undangan atau statute approach dan pendekatan historis (historical approach).

\section{HASIL DAN PEMBAHASAN}

Proses pengadaan Barang/Jasa pemerintah secara elektronik akan lebih meningkatkan dan menjamin terjadinya efisiensi, efektifitas, transparansi, dan akuntabilitas dalam pembelanjaan uang negara. Selain itu, proses Pengadaan Barang/Jasa Pemerintah secara elektronik ini juga dapat lebih menjamin tersedianya informasi, kesempatan usaha, serta

7 Suryanto, "Polisi selidiki dugaan sabotase laman LPSE Trenggalek", diakses dari http://www.antaranews.com/berita/312481/polisi-selidiki-dugaan-sabotase-laman-lpse-trenggalek pada tanggal 27 September 2016 pukul 15.17.

${ }^{8}$ Ibid.

9 Pasal 17 Ayat (2) UU Nomor 11 Tahun 2008 Tentang Informasi dan Transaksi Elektronik.

10 Karyono, 2013, "Forensic Fraud", Andi Yogyakarta, Yogyakarta, h. 8.

11 Ibid., h.3. 
mendorong terjadinya persaingan yang sehat dan terwujudnya keadilan (non discriminative) bagi seluruh pelaku usaha yang bergerak di bidang Pengadaan Barang/Jasa Pemerintah. ${ }^{12}$

Jadi dapat disimpulkan bahwa E-Procurement merupakan alat untuk:

1. Meningkatkan kualitas dan kuantitas dari layanan ke masyarakat;

2. Mendukung terjadinya proses pemerintahan yang bersih dan transparan;

3. Membantu melakukan perbaikan terhadap organisasi di dalam tubuh pemerintahan, perbaikan manajemen waktu atau jam kerja pegawai pemerintahan agar semakin produktif, manajemen keuangan di dalam pemerintahan (untuk menghapus korupsi), karena peluang untuk kontak langsung antara penyedia barang/jasa dengan panitia pengadaan semakin kecil.

Sistem Pengadaan Secara Elektronik dapat dilakukan melalui 2 cara yaitu E-Tendering dan E-Purchasing.

\section{E-Tendering}

Tata cara pemilihan Penyedia Barang/Jasa yang dilakukan secara terbuka dan dapat diikuti oleh semua Penyedia Barang/Jasa yang terdaftar pada sistem pengadaan secara elektronik dengan cara menyampaikan satu kali penawaran dalam waktu yang telah ditentukan. ${ }^{13}$ Proses E-Tendering di LPSE Kabupaten Trenggalek meliputi pengumuman pengadaan barang/jasa sampai dengan pengumuman pemenang yang dilaksanakan menggunakan sistem pengadaan secara elektronik. Sedangkan sirkulasi dokumen ETendering dalam sistem pengadaan secara elektronik digambarkan dalam gambar berikut:

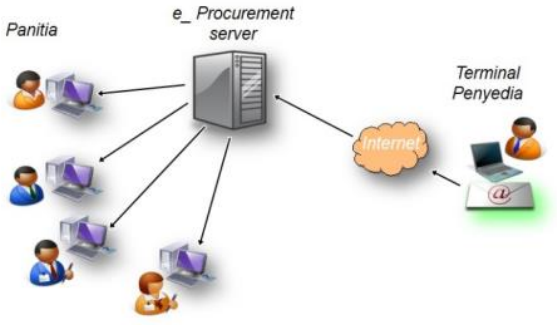

\section{Gambar 4.1. Sirkulasi Dokumen (E-Tendering)}

E-Tendering secara umum diatur dalam Pasal 109 Perpres Nomor 54 Tahun 2010, sedangkan pengaturan secara khusus terdapat pada Peraturan Kepala Lembaga Kebijakan Pengadaan Barang/Jasa Pemerintah Nomor 1 Tahun 2011 yang mengatur secara jelas tata cara E-Tendering.

Adapun tata cara E-Tendering setiap tahapannya adalah sebagai berikut: ${ }^{14}$

\footnotetext{
${ }^{12}$ Ibid.

13 Patria Susanto, "Aspek Regulasi Pengadaan Barang/Jasa Secara Elektronik", diunduh dari http://lpse.tangerangkota.go.id/eproc/publicberitadetail.filedownload:download/32303234363036 363b32;jsessionid=21C91CC462F688C9EBACEDDBD670AB26?t:ac $=405066$, pada tanggal 17 April 2017 Pukul 22.53

14 Susan Andriyani, Op. cit, h. 62
} 


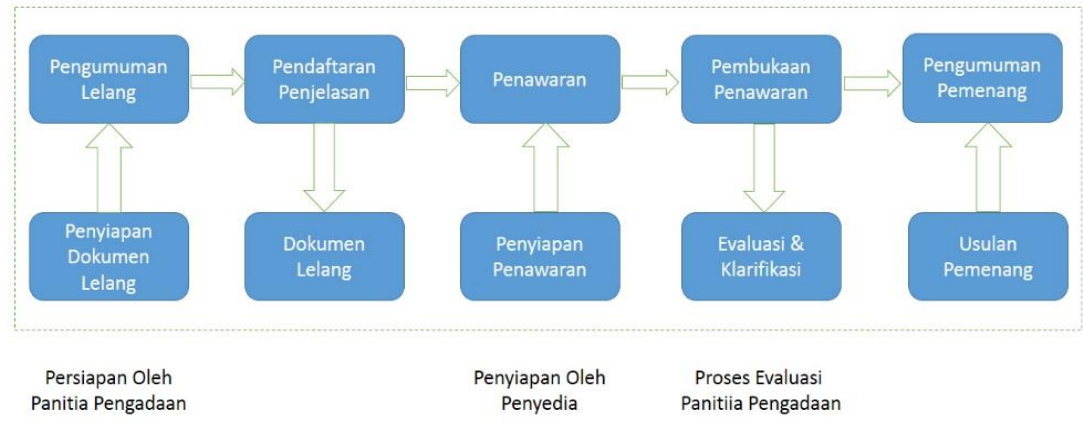

Gambar 4.2. Siklus Tata Cara E-Tendering

Dalam proses tahapan E-Tendering kesemua data menggunakan Sistem Pengadaan Secara Elektronik, mulai dari pengumuman lelang yang diumumkan melalui situs lpse.trenggalekkab.go.id/eproc4. Apabila pada masa pendaftaran tersebut ada pertanyaan dari peserta yang ingin mengikuti pelelangan, peserta dapat mengajukan pertanyaan secara online melalui aplikasi SPSE, pertanyaan tersebut langsung dijawab oleh Unit Layanan Pengadaan (ULP) Kabupaten Trenggalek atau Panitia Pengadaan. Tahap selanjutnya adalah adalah pemasukkan kualifikasi peserta lelang, data kualifikasi disampaikan melalui formulir elektronik isian kualifikasi yang tersedia pada aplikasi SPSE. Setelah data kualifikasi diisi dengan lengkap dan benar, maka berikutnya adalah pemasukkan penawaran oleh peserta lelang. Dokumen penawaran disampaikan dalam bentuk file yang diunggah melalui aplikasi SPSE. Surat penawaran yang disampaikan oleh peserta lelang secara elektronik ini tidak memerlukan tanda tangan basah dan stempel. Surat penawaran ditandatangani secara elektronik oleh pimpinan/direktur perusahaan atau kuasa yang ditunjuk dengan surat kuasa. Setelah jangka waktu pemasukkan dokumen penawaran berakhir, dilanjut dengan tahap pembukaan penawaran. Pada tahap pembukaan penawaran, ULP Kabupaten Trenggalek mengunduh (download) dan melakukan deskripsi file penawaran dengan menggunakan Aplikasi Pengamanan Dokumen (APENDO). ULP Kabupaten Trenggalek dapat terlebih dahulu melakukan evaluasi terhadap 3 (tiga) penawar terendah, melalui proses evaluasi (administrasi dan teknis, harga, kualifikasi) yang dilakukan secara manual (offline) diluar aplikasi SPSE, selanjutnya hasil evaluasi tersebut dimasukkan ke dalam aplikasi SPSE. ULP wajib melakukan klarifikasi kepada penerbit surat jaminan tentang keabsahan dan substansi jaminan penawaran karena ketidakabsahan atau kemungkinan penolakan klaim jaminan terhadap softcopy surat jaminan yang ditunjukkan oleh ULP dapat berakibat pada gugurnya syarat administrasi. Pembuktian kualifikasi dengan meminta dokumen penawaran asli dilaksanakan terhadap calon pemenang. Setelah dilakukan evaluasi dan klarifikasi, maka ULP mendapatkan pemenang dan aplikasi SPSE secara otomatis akan mengirimkan pemberitahuan (termasuk melalui $e$-mail) kepada pemenang pemilihan.

Peserta lelang dapat mengajukan sanggahan kepada ULP Kabupaten Trenggalek. Peserta lelang hanya dapat mengirim 1 (satu) kali sanggahan kepada ULP melalui aplikasi SPSE dan ULP menjawan sanggahan tersebut melalui aplikasi SPSE juga. Setelah masa sanggahan selesai, Panitia Pembuat Komitmen (PPK) membuat Surat Penunjukan Penyedia Barang/Jasa (SPPBJ) dengan menggunakan fasilitas dan 
berdasarkan format penulisan yang tersedia dalam Aplikasi SPSE. Setelah SPPBJ diterbitkan dilanjutkan pemenang lelang dengan membawa dokumen penawaran asli, melakukan penandatanganan kontrak dengan PPK yang dilakukan diluar SPSE. ${ }^{15}$

Terlihat dari penandatanganan kontrak dengan PPK yang dilakukan diluar SPSE dapat disimpulkan bahwa E-Procurement menggunakan internet sebagai instrumen bantu, namun bukan berarti lahirnya kesepakatan antara panitia pengadaan dengan peserta penyedia barang terjadi dalam internet sebagaimana e-commerce. E-Procurement belum murni paperless transaction (sehingga keanbsahan kontraknya tidak perlu diragukan), karena selain memasukkan data lewat aplikasi SPSE, penyedia barang/jasa diwajibkan pula memberikan dokumen penawaran dan data lain yang terkait dalam bentuk hard copy (dokumen asli) kepada panitia pengadaan. Akseptasi terjadi pada saat dikeluarkannya Surat Keputusan Penetapan Penyedia Barang dan Jasa (SKPPBJ) yang menunjuk salah seorang peserta lelang. Dengan kata lain, E-Procurement masih menekankan pada physical form (bentuk nyata dan konkret) atau paper based transaction yaitu belum murni menjalankan perdagangan secara elektronik layaknya e-commerce, sehingga kaidah hukum perjanjiaan tetap berlaku. ${ }^{16}$

\section{E-Purchasing}

Tata cara pengadaan barang/jasa melalui pembelian Barang/Jasa melalui sistem katalog elektronik (e-Katalog). ${ }^{17}$ E-Purchasing secara umum diatur dalam Pasal 110 Perpres Nomor 54 Tahun 2010. E-Purchasing dengan sistem katalogisasi produk dapat meminimalkan potensi penyelewengan.

Menurut Tjipto, salah satu cara aksi pencegahan korupsi yang dapat dilakukan LKPP adalah mengkatalogkan produk. Sebab, melalui penayangan produk ke dalam ekatalog, informasi harga dan spesifikasi item menjadi sangat transparan. ${ }^{18}$ Hal ini karena sistem dan keterbukaan informasi setiap produk, secara tidak langsung, telah menekan potensi dalam melakukan tindak kecurangan, seperti upaya mark-up harga produk. Dalam aplikasi E-Purchasing terdapat 2 (dua) alur proses yaitu19:

\footnotetext{
15 Peraturan Kepala Lembaga Kebijakan Pengadaan Barang/Jasa Pemerintah Nomor 1 Tahun 2011 tentang Tata Cara E-Tendering.

${ }^{16}$ Susan Andriyani, op.cit., h. 4

17 Patria Susanto, op.cit., h. 5

18 LKPP, "Katalogisasi Produk Minimalkan Potensi Penyelewengan", diakses dari https://ekatalog.lkpp.go.id/page/konten_dinamis/view/24?km=blog_roll tanggal 22 April 2017 Pukul 07.52 .

19 LKPP, "Petunjuk Penggunaan Aplikasi e-Purchasing Produk Barang dan Jasa Pemerintah", diunduh dari https://e-katalog.lkpp.go.id/files/upload/konten/Panduan/USER\%20GUIDE\%20ePurchasing\%20penyedia.pdf pada tanggal 22 April 2017 Pukul 7:37.
} 


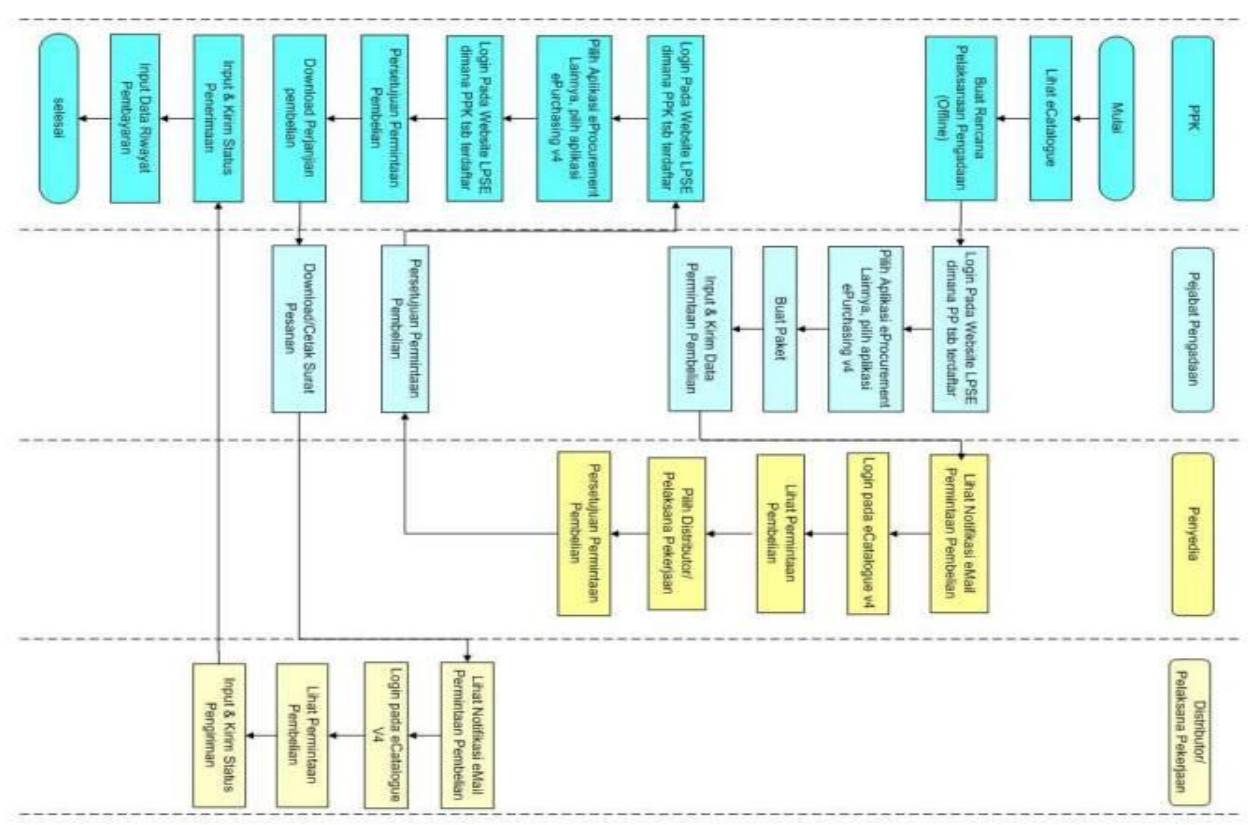

Gambar 4.3. Alur Proses e-Purchasing Produk Barang/Jasa Pemerintah dalam Aplikasi (Tanpa Fitur Negosiasi Harga)

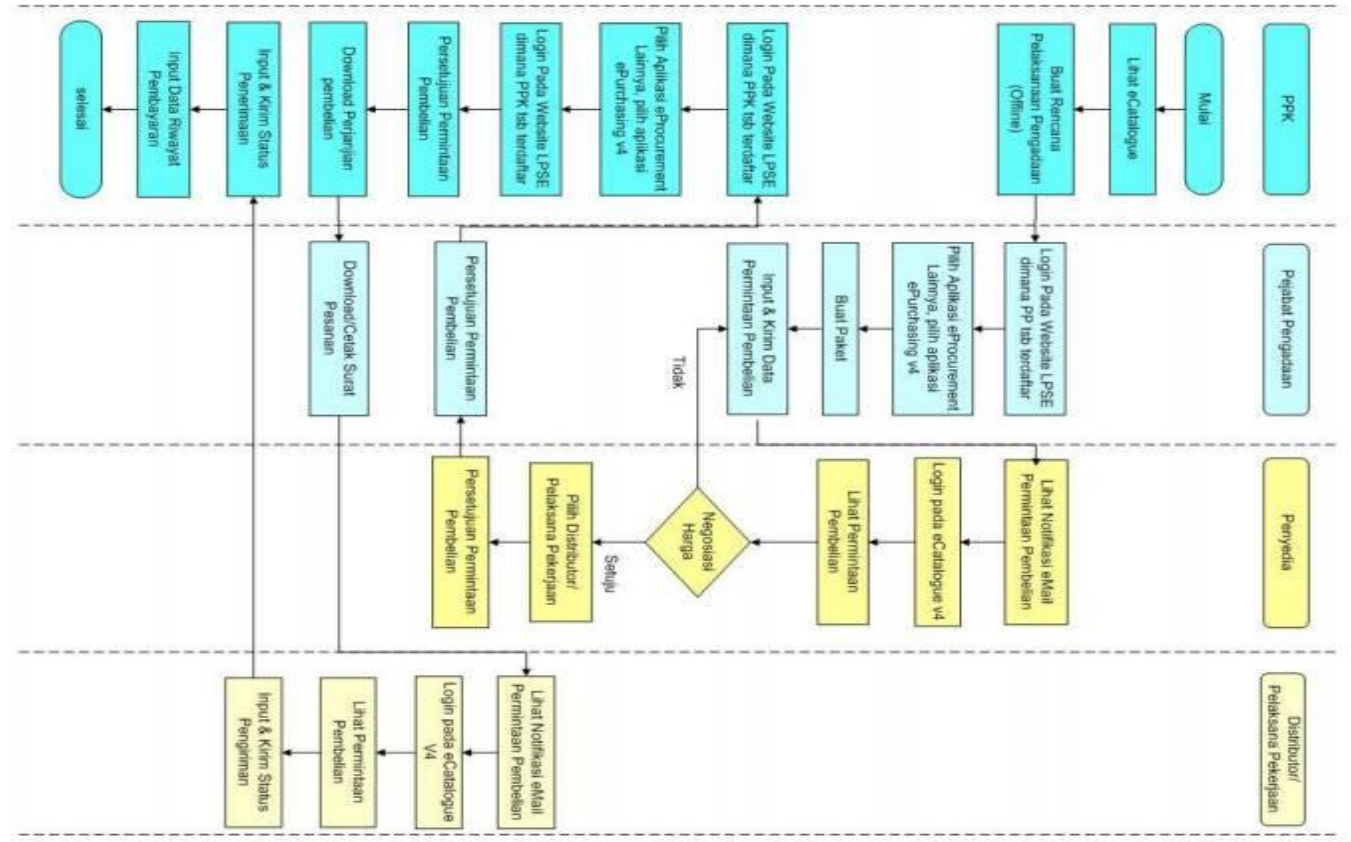

Gambar 4.4. Alur Proses e-Purchasing Produk Barang/Jasa Pemerintah dalam Aplikasi (dengan Fitur Negosiasi Harga)

Dalam realisasinya masih banyak kelemahan atau kekurangan dari sistem katalog elektronik. Berdasarkan hasil pemeriksaan Badan Pemeriksa Keuangan (BPK) disimpulkan kegiatan penyelenggaraan sistem katalog elektronik kurang efektif.20

Penyelenggaraan sistem katalog elektronik belum sepenuhnya didukung dengan sistem informasi yang memadai. Permasalahan tersebut diantaranya aplikasi dalam

20 BPK, "Ikhtisar Hasil Pemeriksaan Semester II Tahun 2015", diunduh dari http://www.bpk.go.id/ihps tanggal 22 April 2017 Pukul 13.51. 
penyelenggaraan katalog elektronik (aplikasi e-catalogue dan e-purchasing) belum sepenuhnya dapat menampilkan informasi yang dibutuhkan pengguna katalog.

Hambatan yang terjadi dalam pengadaan barang/jasa secara elektronik di Kabupaten Trenggalek dibagi dalam 3 aspek yaitu:

\begin{tabular}{|c|c|}
\hline \multicolumn{2}{|r|}{ ASPEK TINGKAT KEMAMPUAN SUMBER DAYA MANUSIA } \\
\hline \multicolumn{2}{|c|}{ Panitia Lelang: } \\
\hline 1. & $\begin{array}{l}\text { Kurangnya pemahaman Panitia Lelang terhadap Perpres No. 54/2010 dan } \\
\text { perubahannya. }\end{array}$ \\
\hline 2. & $\begin{array}{l}\text { Panitia pengadaan sebagian besar masih mengalami kesulitan untuk menggunakan } \\
\text { dan memahami aplikasi E-Procurement. }\end{array}$ \\
\hline 3. & $\begin{array}{l}\text { Perubahan personel pengadaan akibat mutasi pegawai juga merupakan masalah } \\
\text { yang dihadapi pada saat implementasi. }\end{array}$ \\
\hline 4. & Kurangnya Personel Panitia Lelang. \\
\hline 5. & $\begin{array}{l}\text { Tingkat kelalaian yang sangat tinggi dalam penggunaan password dan kunci } \\
\text { kerahasiaan lainnya oleh user. }\end{array}$ \\
\hline 6. & hlian teknis. \\
\hline 7. & ktur IT. \\
\hline \multicolumn{2}{|c|}{ Penyedia Barang/Jasa : } \\
\hline 1. & $\begin{array}{l}\text { Kurangnya pemahaman Penyedia Barang/Jasa terhadap Perpres No. 54/2010 dan } \\
\text { perubahannya. }\end{array}$ \\
\hline 2. & Penyedia barang/jasa banyak yang belum memahami aplikasi E-Procurement. \\
\hline 3. & $\begin{array}{l}\text { Keharusan memilih harga terendah sehingga peserta cenderung banting harga } \\
\text { sehingga kualitas dari hasil pengadaan perlu dipertanyakan. }\end{array}$ \\
\hline 4. & Besarnya sorotan publik sehingga menimbulkan efek enggan bagi peserta lelang. \\
\hline 5. & lam mencukupi persyaratan dalam dokumen penawaran. \\
\hline 6. & Kurangnya keahlian teknis. \\
\hline \multicolumn{2}{|r|}{$\begin{array}{l}\text { ASPEK KONDISI INFRASTRUKTUR DAN PENGATURAN SISTEM PENDUKUNG E- } \\
\text { PROCUREMENT }\end{array}$} \\
\hline 1. & $\begin{array}{l}\text { Infrastruktur teknis yang kurang memadai dan berkurangnya integrasi dengan } \\
\text { rekanan. }\end{array}$ \\
\hline 2. & $\begin{array}{l}\text { Ketersediaan fasilitas koneksi internet dan fasilitas pendukung lainnya (Ruangan } \\
\text { Server, AC, UPS, Komputer, CCTV, Ruang Pelatihan, dll) masih sangat terbatas } \\
\text { untuk Panitia Pengadaan. }\end{array}$ \\
\hline 3. & $\begin{array}{l}\text { Terbatasnya Bandwith juga menyebabkan masih sering terjadi kegagalan proses pada } \\
\text { aplikasi E-Procurement. }\end{array}$ \\
\hline 4. & Kurangnya keamanan sistem. \\
\hline 5. & Sistem IT yang terlalu mahal. \\
\hline \multicolumn{2}{|c|}{ ASPEK PENGAWASAN PROSEDUR } \\
\hline 1. & Belum maksimalnya pengawasan. \\
\hline 2. & $\begin{array}{l}\text { Penanganan masalah dalam pelaksanaan lelang menggunakan E-Procurement terlalu } \\
\text { lama prosedurnya. }\end{array}$ \\
\hline 3. & Kurangnya kesiapan instansi dalam mengikuti E-Procurement. \\
\hline 4. & Kurangnya sosialisasi tentang E-Procurement kepada Penyedia Barang/Jasa. \\
\hline
\end{tabular}

Dari ketiga aspek kendala di atas yang paling mendominasi adalah aspek tingkat kemampuan sumber daya manusia dibanding aspek kondisi infrastruktur dan pengaturan sistem pendukung e-procurement serta aspek pengawasan prosedur. Aspek tingkat kemampuan SDM terdiri dari SDM Panitia Lelang dan SDM Penyedia barang/jasa yang masih terdapat banyak kendala dalam E-Procurement. Sumber daya manusia adalah 
sebuah aset atau salah satu faktor yang sangat penting bahkan tidak dapat dilepaskan dari sebuah organisasi ${ }^{21}$, yang harus dikelola dan diberdayakan untuk mencapai tujuan organisasi.

Peraturan Presiden Nomor 4 Tahun 2015 tentang Perubahan Keempat Atas Peraturan Presiden Nomor 54 Tahun 2010 tentang Pengadaan Barang/Jasa Pemerintah dengan sangat terinci dan penuh kehati-hatian telah merumuskan seluruh ketentuan yang berkaitan dengan proses kegiatan pengadaan barang/jasa Pemerintah, tetapi dalam pelaksanaannya masih banyak ditemui persoalan karena perpres ini bersifat sangat teknis serta peraturannya terpisah-pisah, tersebar dalam petunjuk teknis dan petunjuk pelaksanaannya.

Kegiatan pengadaan barang/jasa akhirnya memunculkan implikasi negatif pada persoalan yuridis yang sangat rumit. Masalah yuridis itu muncul tidak jarang dipicu oleh sikap berlebihan dari atasan langsung di jajaran pelaksana kegiatan pengadaan barang/jasa maupun ditingkat Pengguna barang/jasa dan adanya persekongkolan antara Pejabat Pengadaan dengan Penyedia barang/jasa untuk bermain curang. Ancaman hukuman nyaris mengintai kerja para Pejabat Pengadaan, Pengguna barang/jasa, dan Penyedia barang/jasa disetiap lini kegiatan pengadaan sejak proses perencanaan kebutuhan sampai diselesaikannya seluruh kegiatan untuk memperoleh Barang/Jasa. ${ }^{22}$

Untuk mendapatkan barang/jasa yang dibutuhkan, Pengguna barang/jasa Pemerintah yang diawali dengan proses perencanaan kebutuhan sampai diselesaikannya seluruh kegiatan untuk memperoleh barang/jasa sesuai kebutuhannya melalui Pelaksana kegiatan pengadaan barang/jasa Pemerintah menentukan dan menetapkan pihak Penyedia barang/jasa Pemerintah, yaitu Badan Usaha atau Orang perseorangan yang menyediakan Barang/Pekerjaan Konstruksi/Jasa Konsultansi/Jasa Lainnya dan Penyedia melalui Swakelola, khusus untuk kegiatan pengadaan barang/jasa yang pekerjaannya direncanakan, dikerjakan, dan/atau diawasi sendiri oleh $\mathrm{K} / \mathrm{L} / \mathrm{D} / \mathrm{I}$ sebagai penanggung jawab anggaran, instansi pemerintah lain dan/atau kelompok masyarakat (vide: Pasal 1 angka 12 dan 20 Perpres No. 70 Tahun 2012).

Dalam kegiatan pengadaan barang/Jasa terdapat dua subjek hukum yang mempunyai kesetaraan kedudukan dengan memiliki hak dan kewajiban yang sama, yaitu23:

- Pengguna barang/Jasa yang diwakili oleh Pejabat Pembuat Komitmen (PPK), yaitu pemerintah/instansi yang membutuhkan barang/jasa.

- Penyedia Barang/Jasa yaitu Badan Usaha atau Orang perorangan yang menyediakan Barang/Pekerjaan Konstruksi/Jasa Konsultansi/atau Jasa Lainnya, atau juga Penyedia melalui swakelola.

Dalam ketentuan Pasal 11 huruf "d" Perpres Pengadaan Barang/Jasa Pemerintah, ditetapkan bahwa Pejabat Pembuat Komitmen (PPK) melaksanakan Kontrak dengan

21 Wikipedia, "Sumber Daya Manusia", diakses dari https://id.wikipedia.org/wiki/Sumber_daya_manusia, tanggal 26 April 2017 Pukul 8.29.

22 E. Suparman, 2014, "Aspek Hukum Perdata Dalam Pelaksanaan Pengadaan Barang/Jasa Pemerintah Pada Rancangan Undang-Undang tentang pengadaan Barang/Jasa", didownload dari http://lpse.pematangsiantarkota.go.id/eproc/index.filedownload:download/35303836343532363b31, pada tanggal 3 Oktober 2016 Pukul 23.22.

23 Ibid., h.20. 
Penyedia Barang/Jasa. Hal ini berarti bahwa dalam kegiatan pengadaan barang/jasa pemerintah terdapat hubungan hukum perdata antara Pengguna dan Penyedia barang/jasa pemerintah yang didasarkan pada adanya pelaksanaan kontrak untuk memenuhi kebutuhan Pengguna barang/jasa yang dilaksanakan pemenuhannya oleh Penyedia barang/jasa. Kontrak yang dibuat oleh pemerintah dalam pengadaan barang/jasa ini bersifat multi aspek dan memilki karakter yang sangat khas.

Sekalipun hubungan hukum yang terbentuk antara pemerintah dengan mitranya adalah hubungan kontraktual, tetapi di dalamnya terkandung tidak saja hukum privat, tetapi juga hukum publik. Apabila dalam kontrak komersil para pihak mempunyai kebebasan yang sangat luas dalam mengatur hubungan hukum atau mengatur kewajiban kontraktual mereka, maka dalam kontrak pengadaan oleh pemerintah, kebebasan itu tidak sepenuhnya berlaku sebab terhadap kontrak ini berlaku rezim hukum khusus.

Dengan demikian, pelaksanaan pemenuhan pengadaan barang/jasa pemerintah merupakan perbuatan hukum perdata yang tunduk pada KUH Perdata yang diberlakukan dengan rezim khusus. ${ }^{24}$ Aspek hukum fraud atau kecurangan dalam pengadaan barang/jasa secara elektronik menurut Peraturan Presiden Nomor 4 Tahun 2015 tentang perubahan keempat atas Peraturan Presiden Nomor 54 Tahun 2010 Tentang Pengadaan Barang/Jasa Pemerintah masih memerlukan penyempurnaan, karena belum ada aturan khusus mengenai kecurangan/fraud dalam pengadaan barang/jasa Pemerintah.

Untuk mengurangi kecurangan/fraud dalam pengadaan barang/jasa pemerintah, yang perlu diperhatikan adalah pengawasan. Pengawasan yang baik akan mengurangi kecurangan, keterlibatan Aparat Pengawasan Intern Pemerintah (APIP) dalam proses pengadaan barang/jasa pemerintah dinilai sangat penting karena mampu mendeteksi dan memberikan koreksi terhadap penyimpangan pengadaan sejak awal. APIP melakukan pemeriksaan sesuai dengan tugas pokok dan fungsinya, yang juga disebutkan pada pasal 116 Perpres Nomor 54 Tahun 2010 Tentang Pengadaan Barang/Jasa Pemerintah.

\section{PENUTUP}

Dalam proses pengadaan barang/jasa secara elektronik di Kabupaten Trenggalek masih membutuhkan sosialisasi kepada pihak penyedia karena masih banyak pihak penyedia yang kebingungan/belum mengerti proses E-Procurement.

E-Procurement di Kabupaten Trenggalek masih membutuhkan pengembangan dalam berbagai aspek, terutama dalam aspek tingkat kemampuan Sumber Daya Manusia dan aspek kondisi infrastruktur dan pengaturan sistem pendukung E-Procurement serta dalam aspek pengawasan prosedur, agar bisa lebih berkompeten dan ahli dalam pengadaan barang/jasa secara elektronik.

Fraud/kecurangan dalam E-Procurement menurut Perpres No. 4 Tahun 2015 Tentang Perubahan Keempat Atas Peraturan Presiden Nomor 54 Tahun 2010 Tentang Pengadaan Barang/Jasa Pemerintah belum ada aturan khusus yang mengaturnya, pengaturan pengadaan barang/jasa sudah seharusnya diberlakukan dalam sebuah produk hukum setingkat Undang-Undang. Karena kemajuan teknologi yang semakin pesat, yang diikuti juga oleh kemajuan kecurangan dalam teknologi juga semakin tinggi.

${ }^{24}$ Ibid., h. 21 


\section{DAFTAR PUSTAKA}

BPK, "Ikhtisar Hasil Pemeriksaan Semester II Tahun 2015", diunduh dari http://wwww.bpk.go.id/ihps, tanggal 22 April 2017 Pukul 13.51.

Direktorat e-Procurement LKPP, “Buku manual SPSE v.3.5”, 2012.

E. Suparman, 2014, "Aspek Hukum Perdata Dalam Pelaksanaan Pengadaan Barang/Jasa Pemerintah Pada Rancangan Undang-Undang tentang pengadaan Barang/Jasa", diunduh dari http://pse.pematangsiantarkota.go.id/eproc/index.filedownload:download/35303836343532363 b31, pada tanggal 3 Oktober 2016 Pukul 23.22.

Karyono, "Forensic Fraud", Andi Yogyakarta, Yogyakarta, 2013.

LKPP, "Katalogisasi Produk Minimalkan Potensi Penyelewengan", diakses dari https://ekatalog.lkpp.go.id/page/konten_dinamis/view/24?km=blog_roll, tanggal 22 April 2017 Pukul 07.52.

LKPP, "Petunjuk Penggunaan Aplikasi e-Purchasing Produk Barang dan Jasa Pemerintah", diunduh dari https:/lekatalog.lkpp.go.id/files/upload/konten/Panduan/USER\%20GUIDE\%20e-

Purchasing\%20penyedia.pdf, pada tanggal 22 April 2017 Pukul 7:37.

Maria Avilla Cahya Arfanti, "Pelaksanaan Sistem E-Procurement dalam Pengadaan Barang/Jasa Pemerintah Untuk Mencegah Terjadinya Persekongkolan Tender", diunduh dari http://download.portalgaruda.org/article.php?article $=188095 \mathcal{E} v a l=6466 \mathcal{E}$ title $=$ PELAKSANA AN\%20SISTEM\%20EPROCUREMENT\%20DALAM\%20PENGADAAN\%20BARANG/IASA\%20PEMERINTA H\%20UNTUK\% 20MENCEGAH\% 20TERJADINYA\%20PERSEKONGKOLAN\%20TEND ER\%20(Studi\%20di\%20Dinas\%20Pekerjaan\%20Umum,\%20Perumahan,\%20dan\%20Penga wasan\%20Bangunan\%20Kota\%20Malang), pada tanggal 20 April 2017 Pukul 08.31.

Patria Susanto, "Aspek Regulasi Pengadaan Barang/Jasa Secara Elektronik", diunduh dari http://pse.tangerangkota.go.id/eproc/publicberitadetail.filedownload: download/32303234363036363b32;jsessionid=21C91CC462F688C9EBACEDDBD670AB26? t:ac=405066, pada tanggal 17 April 2017 Pukul 22.53.

Peraturan Kepala Lembaga Kebijakan Pengadaan Barang/Jasa Pemerintah Nomor 1 Tahun 2011 tentang Tata Cara E-Tendering.

Peraturan Presiden Republik Indonesia Nomor 54 Tahun 2010 Tentang Pengadaan Barang/Jasa Pemerintah.

Perpustakaan Nasional, "Panduan Lengkap UU Pengadaan Barang $\mathcal{E}$ Jasa", Cet I, Laksana, Yogyakarta, 2016.

Suryanto, "Polisi selidiki dugaan sabotase laman LPSE Trenggalek", diakses dari http://www.antaranews.com/berita/312481/polisi-selidiki-dugaan-sabotase-laman-lpsetrenggalek, pada tanggal 27 September 2016 pukul 15.17.

Susan Andriyani , "Analisis Efektivitas Dalam Penerapan Pengadaan Barang Dan Jasa Secara Elektronik (E-Procurement) Serta Peranan Lembaga Pengawas Terhadap Pengadaan Barang Dan Jasa Pemerintah", diunduh dari http://ib.ui.ac.id/file?file=digital/20302458-T30642\%20 \%20Analisis\%20efektivitas.pdf, pada tanggal 20 April 2017 Pukul 08:31.

Undang-Undang Nomor 11 Tahun 2008 tentang Informasi dan Transaksi Elektronik.

Wikipedia, "Sumber Daya Manusia", diakses https://id.wikipedia.org/wiki/Sumber_daya_manusia, tanggal 26 April 2017 Pukul 08.29. 